\title{
PLANT ANALYSIS APPLICATION FOR ENVIRONMENTALLY FRIENDLY FERTILIZATION OF WINTER BARLEY (HORDEUM VULGARE L.)
}

\author{
SURÁNYI, S. ${ }^{{ }^{*}}-$ IZSÁKI, Z. ${ }^{2}$ \\ ${ }^{1}$ Plant Protection and Soil Conversation Division, Agricultural Department, Hódmezövásárhely \\ District Office, Government Office of Csongrád County, Hódmezövásárhely, P.O.B. 99, 6800 \\ Hungary \\ (phone: +36-70-611-5105) \\ ${ }^{2}$ Faculty of Agricultural and Economic Sciences, Szent István University, Szarvas, P.O.B. 3, \\ 5540 Hungary \\ (e-mail: izsaki.zoltan@gk.szie.hu, phone: +36-66-313-311) \\ *Corresponding author \\ e-mail: suranyi.szilvia@csongrad.gov.hu \\ (Received $5^{\text {th }}$ Jun 2018; accepted $1^{\text {st }}$ Aug 2018)
}

\begin{abstract}
The aim of the work was to improve fertilisation recommendations for winter barley by investigating the effect of basic nitrogen $(\mathrm{N})$ fertilisation $\left(0,40,80,120 \mathrm{~kg} \mathrm{ha}^{-1}\right.$ year $\left.^{-1}\right)$ on the nutritional status of this crop in a long-term mineral fertilisation experiment involving clearly distinct nutrient supply levels and by determining limiting values indicative of a satisfactory level of nutrition for nitrogen $(\mathrm{N})$, phosphorus $(\mathrm{P})$, potassium $(\mathrm{K})$, sodium $(\mathrm{Na})$, calcium $(\mathrm{Ca})$ and magnesium $(\mathrm{Mg})$ concentrations. Rising $\mathrm{N}$ supply levels gradually increased the $\mathrm{N}$ content of the aboveground organs of barley, reaching a maximum (4.11-5.61 $\mathrm{N} \%$ ) at the $120 \mathrm{~kg} \mathrm{~N} \mathrm{ha}^{-1}$ dose. On this soil, which was well supplied with phosphorus, higher $\mathrm{N}$ levels only resulted in a significant increase in the $\mathrm{P}$ content of barley in two years. The soil was also well supplied with potassium, $\mathrm{N}$ fertilisation enhanced the $\mathrm{K}$ concentrations of winter barley at tillering in most years, but generally had no influence on the $\mathrm{Na}, \mathrm{Ca}$ and $\mathrm{Mg}$ content of barley. In the tillering phase the nutritional status of barley was satisfactory at the following concentrations: $3.70-5.80 \mathrm{~N} \%, 0.45-0.75 \mathrm{P} \%, 3.50-5.02 \mathrm{~K} \%, 0.20-0.60 \mathrm{Na} \%, 0.40-0.60 \mathrm{Ca} \%$ and $0.18-0.30 \mathrm{Mg} \%$.
\end{abstract}

Keywords: tillering, macroelements, microelements, nutrient concentration

\section{Introduction}

Investigations on the nutritional status of winter barley and the determination of limiting values for nutrient supply levels for use in diagnostic plant analysis have been an important area of fertilisation research for many decades, but few papers have been published in this field in recent years.

Although applying more nitrogen $(\mathrm{N})$ helps achieve the desired yield (West et al., 2016; Mazur and Mazur, 2015), but results in greater levels of environmental pollution (Wang et al., 2016). According to various authors (Dobermann, 2005; Sebilo et al., 2013) 30-65\% of the applied $\mathrm{N}$ fertilizer is taken up by crops. In the opinion of Roberts (2008) nutrient loss to the environment is only a concern when fertilizers or manures are applied at rates above agronomic need. The rate of uptake and partition of $\mathrm{N}$ is largely determined by supply and demand during various stages of plant growth. The $\mathrm{N}$ is needed for early tiller development of barley to set up the crop for high yield potential (Shafi et al., 2011). The $\mathrm{N}$ fertilisation of winter barley should be based on soil and plant analysis. Soil analysis is generally carried out prior to sowing, but a combination of monitoring the mineral $\mathrm{N}$ content $\left(\mathrm{N}_{\text {min }}\right)$ during the vegetation period and plant 
analysis is rarely applied in Hungary. Plant analysis is of outstanding importance in checking the nutritional status of the crop, and its efficiency improves with the number of nutrients analysed (Németh et al., 2010). Plant analysis can play a major role when diagnosing mineral nutrition problems (Munson, 1998). Comparing soil and plant analysis results can greatly assist in the interpretation (Jones, 1998), but may have an adverse impact on the interpretation of plant analysis results (Munson, 1998). The dilution effect makes the interpretation of plant analysis results difficult, but it can be taken into account by relating plant data to a certain stage of growth (Roy et al., 2006). Mengel (1972) emphasised that if plant analysis is to be suitable for use in fertilisation recommendations, it is essential to determine the limiting concentrations representative of nutritional status, which is primarily the task of scientists (Németh et al., 2010; Izsáki, 2014). The optimum values for individual plant species are given, as the physiological requirements of the plant are similar in all regions and soils, only fluctuating over a narrow range (Kádár, 1992). It was suggested by Tarnawa et al. (2017) that reference values should be determined not only for each species but also for each cultivar, but this is complicated by the large choice of cultivars, the frequent changes in the cultivar grown and the time required to elaborate limiting values for nutrient supply levels (Izsáki, 2015). Various authors (Reuter and Robinson, 1997; Elek and Kádár, 1980) give a fairly wide range of limiting values (2.50-5.25\%) for satisfactory $\mathrm{N}$ supplies to winter barley during the tillering phenophase. When judging the nutritional status of winter barley it is not sufficient to determine the $\mathrm{N}$ concentration; interactions between $\mathrm{N}$ and other nutrients should also be investigated, together with the various nutrient ratios. These were considered by Kádár and Lásztity (1981) to be the key components of plant analysis. In classical papers on plant analysis, nutrient content was regarded as the quantitative and nutrient ratios as the qualitative indicator of nutritional status (Németh et al., 2010; Kádár and Lásztity, 1981). Various interactions can be detected in the course of $\mathrm{N}$ nutrition, of which the N/phosphorus $(\mathrm{P})$, $\mathrm{N} /$ potassium $(\mathrm{K}), \mathrm{N} /$ magnesium $(\mathrm{Mg}), \mathrm{N} /$ calcium $(\mathrm{Ca})$ and $\mathrm{N} /$ copper $(\mathrm{Cu})$ ratios are the most important (Németh et al., 2010; Armstrong, 1998; Debreczeniné and Sárdi, 1999; Usherwood and Segars, 2001). The interaction between $\mathrm{N}$ and other nutrients is still controversy among the reports available (Shah et al., 2017). Relatively few papers have been published on the $\mathrm{N}$ nutritional status and nutrient interactions of winter barley at tillering, and these cannot be regarded as up-to-date results due to the rapid genetic gain achieved by developments in breeding.

The aim of this paper was to describe the effect of $\mathrm{N}$ supply levels on the nutrient content of winter barley at tillering and on interactions between the nutrients, based on long-term mineral fertilisation experiments, and to determine limiting values for nutrient supply levels, which can be used to judge the nutritional status of winter barley in the tillering phase.

\section{Materials and methods}

\section{Long-term mineral fertilisation experiment}

The long-term mineral fertilisation experiment was set up at the Experimental Station of the Faculty of Economic, Agricultural and Health Sciences of Szent István University in Hungarian Great Plain, Szarvas, Hungary in 1989 (Fig. 1). The soil of the experimental station, a chernozem meadow soil calcareous in the deeper layers, had the following parameters: depth of the humus-containing layer $85-100 \mathrm{~cm}, \mathrm{pH}$ potassium 
chloride $(\mathrm{KCl})$ of the ploughed layer 5.0-5.2, humus content 2.8-3.2\%, no calcium carbonate $\left(\mathrm{CaCO}_{3}\right)$ content, upper level of plasticity according to Arany $\left(\mathrm{K}_{\mathrm{A}}\right) 50$, dry matter content $32 \%$. The groundwater level was at an average depth of $300-350 \mathrm{~cm}$. Before the experiment was set up in autumn 1989 the ammonium $\left(\mathrm{NH}_{4}\right)$-lactate ALphosphorus pentoxide $\left(\mathrm{P}_{2} \mathrm{O}_{5}\right)$ content averaged $156 \mathrm{mg} \mathrm{kg}^{-1}$ and the $\mathrm{AL}$ - potassium oxide $\left(\mathrm{K}_{2} \mathrm{O}\right)$ content $322 \mathrm{mg} \mathrm{kg}^{-1}$, and the nutrient supply level of the soil, based on the methods and limiting values officially recognised in Hungary (Buzás et al., 1979), was medium-good for nitrogen $(\mathrm{N})$, good for phosphorus $(\mathrm{P})$, potassium $(\mathrm{K})$, copper $(\mathrm{Cu})$ and zink $(\mathrm{Zn})$, and very good for magnesium $(\mathrm{Mg})$ and manganese $(\mathrm{Mn})$. The experiment included every possible combination $\left(4^{3}\right)$ of four levels each of three factors ( $\mathrm{N}, \mathrm{P}$ and $\mathrm{K}$ fertilisation), giving a total of 64 treatments arranged in a split-split plot design with three replications. Within the three true replications, the $N$ fertiliser treatments were present in 48 internal replications and the P treatments in 16.

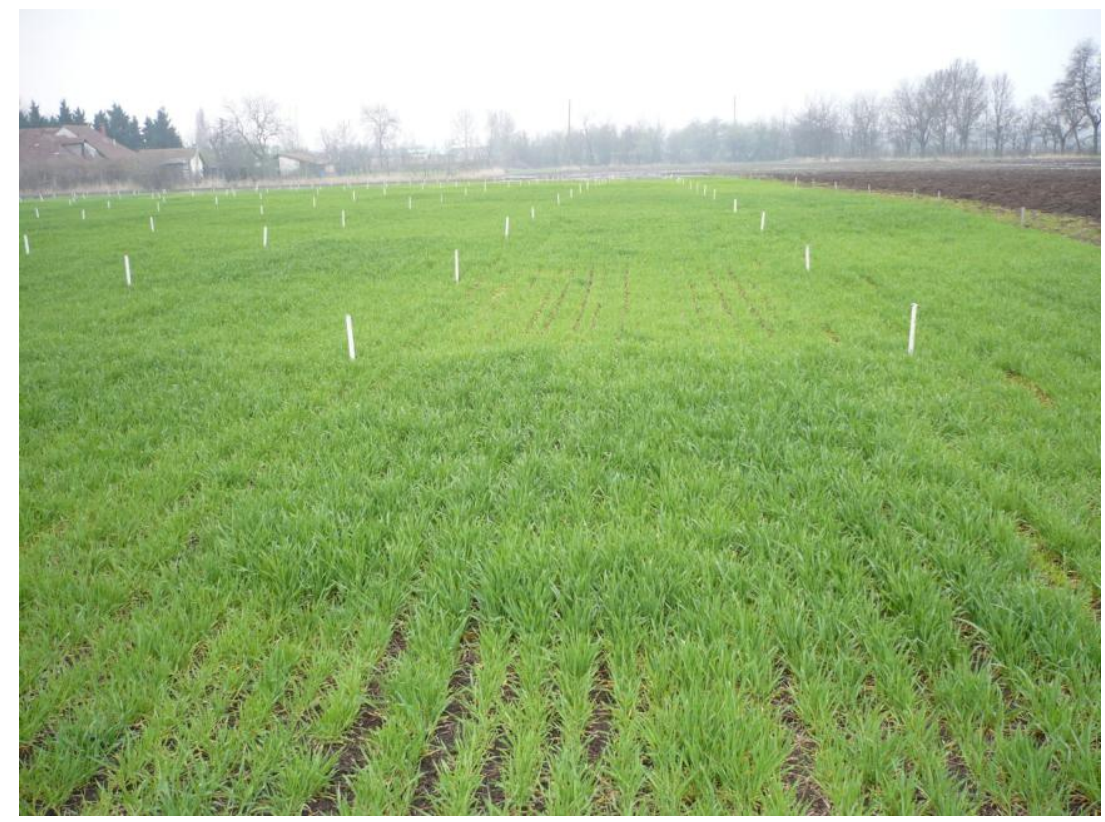

Figure 1. Experimental site

\section{Experimental factors and treatments}

Factor A ( $\mathrm{K}$ fertilisation) involved the following treatments:

$\mathrm{K}_{0}=$ without $\mathrm{K}$ fertilisation,

$\mathrm{K}_{1}=300 \mathrm{~kg} \mathrm{ha}^{-1}$ year $^{-1} \mathrm{~K}_{2} \mathrm{O}$ from 1989-1992, $100 \mathrm{~kg} \mathrm{ha}^{-1}$ year ${ }^{-1}$ from 1993 onwards,

$\mathrm{K}_{2}=600 \mathrm{~kg} \mathrm{ha}^{-1} \mathrm{~K}_{2} \mathrm{O}$ in $1989,1000 \mathrm{~kg} \mathrm{ha}^{-1}$ in 1993 and $600 \mathrm{~kg} \mathrm{ha}^{-1}$ in 2001,

$\mathrm{K}_{3}=1200 \mathrm{~kg} \mathrm{ha}^{-1} \mathrm{~K}_{2} \mathrm{O}$ in $1989,1500 \mathrm{~kg} \mathrm{ha}^{-1}$ in 1993 and $1200 \mathrm{~kg} \mathrm{ha}^{-1}$ in 2001.

Factor $\mathrm{B}$ ( $\mathrm{P}$ fertilisation) involved the following treatments:

$\mathrm{P}_{0}=$ without $\mathrm{P}$ fertilisation,

$\mathrm{P}_{1}=100 \mathrm{~kg} \mathrm{ha}^{-1}$ year $^{-1} \mathrm{P}_{2} \mathrm{O}_{5}$,

$\mathrm{P}_{2}=500 \mathrm{~kg} \mathrm{ha}^{-1} \mathrm{P}_{2} \mathrm{O}_{5}$ in 1989,1993 and 2001,

$\mathrm{P}_{3}=1000 \mathrm{~kg} \mathrm{ha}^{-1} \mathrm{P}_{2} \mathrm{O}_{5}$ in 1989,1993 and 2001 .

Factor $\mathrm{C}$ ( $\mathrm{N}$ fertilisation) involved the following treatments:

$\mathrm{N}_{0}=$ without $\mathrm{N}$ fertilisation,

$\mathrm{N}_{1}=80 \mathrm{~kg} \mathrm{~N} \mathrm{ha}^{-1}$ year $^{-1}$ (40 kg ha ${ }^{-1}$ basic fertiliser $+40 \mathrm{~kg} \mathrm{ha}^{-1}$ top-dressing), 
$\mathrm{N}_{2}=160 \mathrm{~kg} \mathrm{~N} \mathrm{ha}^{-1}$ year $^{-1}$ (80 kg ha ${ }^{-1}$ basic fertiliser $+80 \mathrm{~kg} \mathrm{ha}^{-1}$ top-dressing),

$\mathrm{N}_{3}=240 \mathrm{~kg} \mathrm{~N} \mathrm{ha}^{-1}$ year $^{-1}$ (120 kg ha' ${ }^{-1}$ basic fertiliser $+120 \mathrm{~kg} \mathrm{ha}^{-1}$ top-dressing).

$N_{1 B}=40 \mathrm{~kg} \mathrm{~N} \mathrm{ha}^{-1}$ year ${ }^{-1}$ basic fertiliser

$N_{2 B}=80 \mathrm{~kg} \mathrm{~N} \mathrm{ha}^{-1}$ year ${ }^{-1}$ basic fertiliser

$N_{3 B}=120 \mathrm{~N} \mathrm{ha}^{-1}$ year ${ }^{-1}$ basic fertiliser

The results of the basic fertilizer treatments are included in the paper.

The aim of the periodic application of high rates of $P$ and $K$ fertiliser was to create clearly distinguishable supply levels in the soil in order to investigate different nutritional situations and to determine limiting values for soil nutrient supply levels. The $\mathrm{N}$ basic fertiliser and top-dressing was applied in the form of ammonium nitrate (34\%), the $\mathrm{P}$ as superphosphate (18\%) and the $\mathrm{K}$ as potassium chloride (40 or $60 \%$ ).

\section{Crop management}

Each year four crops were sown in a full crop rotation on $4 \times 192$ plots, where the area of the main plots was $320 \mathrm{~m}^{2}$, the subplots $80 \mathrm{~m}^{2}$ and the sub-subplots $4 \times 5=$ $20 \mathrm{~m}^{2}$. The forecrop of winter barley was fibre hemp (Cannabis sativa) in 2006 and 2007 and canary grass (Phalaris canariensis L.) in 2010 and 2011. The two-row winter barley cultivar GK Stramm was used in the experiment. The results recorded in the long-term experiment in the $17^{\text {th }}-19^{\text {th }}$ years $(2005 / 2006,2006 / 2007,2007 / 2008)$ and in the $22^{\text {nd }}(2010 / 2011)$ and $23^{\text {rd }}(2011 / 2012)$ years are discussed in the present paper. In these years sowing took place between October $8^{\text {th }}$ and November $3^{\text {rd }}$ with a row distance of $12 \mathrm{~cm}$ and 5 million seed/ha. No chemical weed control was required in the experiment. Other plant protection measures were carried out when necessary. Topdressing was applied on a single occasion at the end of tillering after plant sampling. The winter barley was harvested at full maturity using a plot combine at the end of June.

\section{Weather conditions}

The weather conditions during the growing season are presented in Table 1.

Table 1. Weather data of experiment during the period tested, (Szarvas, 2006-2008, 2011 2012)

\begin{tabular}{c|c|c|c|c|c|c}
\hline \multirow{2}{*}{ Year } & \multicolumn{3}{|c|}{ Rainfall, mm } & \multicolumn{3}{c}{ Average temperature, ${ }^{\circ} \mathbf{C}$} \\
\cline { 2 - 7 } & $\begin{array}{c}\text { Winter half } \\
\text { year } \\
\text { (X-III.) }\end{array}$ & $\begin{array}{c}\text { Vegetation } \\
\text { period } \\
\text { (X-VI.) }\end{array}$ & Year total & $\begin{array}{c}\text { Winter half } \\
\text { year } \\
\text { (X-III.) }\end{array}$ & $\begin{array}{c}\text { Vegetation } \\
\text { period } \\
\text { (X-VI.) }\end{array}$ & Year total \\
\hline Average 1901-1975 & 225 & 362 & 538 & 3.4 & 7.5 & 10.6 \\
\hline 2005 & - & - & 721 & - & - & 10.2 \\
\hline $2005 / 2006$ & 204 & 379 & 537 & 2.2 & 6.9 & 10.7 \\
\hline $2006 / 2007$ & 159 & 293 & 548 & 6.5 & 10.2 & 12.2 \\
\hline $2007 / 2008$ & 200 & 370 & 464 & 4.2 & 8.4 & 11.7 \\
\hline $2010 / 2011$ & 282 & 435 & 373 & 3.6 & 8.2 & 11.5 \\
\hline $2011 / 2012$ & 121 & 230 & 363 & 3.1 & 7.9 & 11.5 \\
\hline
\end{tabular}

In the $17^{\text {th }}$ year of the long-term experiment (2005/2006) the rainfall quantity $(379 \mathrm{~mm})$ was slightly higher than the long-term mean $(362 \mathrm{~mm})$, while the mean temperature $\left(6.9^{\circ} \mathrm{C}\right)$ was lower than the long-term mean $\left(7.5^{\circ} \mathrm{C}\right)$. In the year with the least favourable weather (2006/2007) the total rainfall was $69 \mathrm{~mm}$ less than the longterm mean while the mean temperature was $2.7^{\circ} \mathrm{C}$ higher. In $2007 / 2008$ both the 
rainfall quantity and the mean temperature were close to the long-term mean $(370 \mathrm{~mm}$ and $8.4^{\circ} \mathrm{C}$ ). The wettest growing season was the $22^{\text {nd }}$ year of the experiment, with $73 \mathrm{~mm}$ more rain than the long-term mean and a mean temperature $0.7^{\circ} \mathrm{C}$ higher than the mean. In the 2011/2012 growing season the temperature was similar to the longterm mean, while the rainfall quantity $(230 \mathrm{~mm})$ was well below the mean.

\section{Soil contents}

The $\mathrm{K}_{2} \mathrm{O}$ and $\mathrm{P}_{2} \mathrm{O}_{5}$ contents of the soil were determined using the $\mathrm{AL}$ method (Hungarian standard MSZ 20135:1999). When evaluating the results, the $\mathrm{K}$ and $\mathrm{P}$ values recorded in the ploughed $(30 \mathrm{~cm})$ layer were used to represent the $\mathrm{K}$ and $\mathrm{P}$ supply levels in the soil. The $\mathrm{K}$ and $\mathrm{P}$ supply levels given for the various years are those recorded in the autumn of the previous year (Table 2).

Table 2. P and K supplies of the soil, (Szarvas, 2006-2008, 2010-2011)

\begin{tabular}{c|c|c|c|c|c}
\hline \multirow{2}{*}{ Treatment } & \multicolumn{5}{c}{ Years of experiment } \\
\cline { 2 - 5 } & $\mathbf{2 0 0 6}$ & $\mathbf{2 0 0 7}$ & $\mathbf{2 0 0 8}$ & $\mathbf{2 0 1 0}$ & $\mathbf{2 0 1 1}$ \\
\hline \multicolumn{6}{c}{ AL- $\mathrm{K}_{2} \mathrm{O}$ in plought layer $\left(\mathrm{mg} \mathrm{kg}^{-1}\right)$} \\
\hline $\mathrm{K}_{0}$ & 199 & 211 & 235 & 218 & 210 \\
$\mathrm{~K}_{1}$ & 320 & 322 & 345 & 324 & 320 \\
$\mathrm{~K}_{2}$ & 324 & 301 & 322 & 294 & 286 \\
$\mathrm{~K}_{3}$ & 377 & 340 & 375 & 346 & 335 \\
\hline \multicolumn{7}{c}{$\mathrm{AL}-\mathrm{P}_{2} \mathrm{O}_{5}$ in plought layer $\left(\mathrm{mg} \mathrm{kg}^{-1}\right)$} \\
\hline $\mathrm{P}_{0}$ & 141 & 118 & 133 & 118 \\
$\mathrm{P}_{1}$ & 217 & 222 & 181 & 206 & 224 \\
$\mathrm{P}_{2}$ & 186 & 193 & 158 & 194 & 186 \\
$\mathrm{P}_{3}$ & 282 & 273 & 269 & 251 & 233 \\
\hline
\end{tabular}

\section{Plant samples}

Plant samples were taken from $2 \times 1 \mathrm{~m}$ on each plot at tillering (growth stage $4-5$ on the Feekes scale), prior to $\mathrm{N}$ top-dressing, to determine the nutrient content of winter barley. The nutrients $\mathrm{N}, \mathrm{P}, \mathrm{K}$, sodium $(\mathrm{Na})$, calcium $(\mathrm{Ca})$ and magnesium $(\mathrm{Mg})$ were analysed in five years (2006-2008 and 2011-2012) from dried, ground samples of the complete aboveground plant organs. The nutrient contents were determined using the inductively coupled plasma optical emission spectrometry method (ICP-OES) after digestion with first nitric acid and then hydrogen peroxide (MSZ-08-1783-6:1983 3.1., MSZ-08-1783-26-34:1985, MSZ-08-1783-36:1985). The data are given in terms of dry matter. In the present paper is discussed the effect of basic $\mathrm{N}$ fertilisation.

\section{Statistical analysis}

Statistical analysis was performed by means of analysis of variance followed by Student's t-test and least significant differences (LSD) at the 0.05 probability level, using the SPSS program, version 15.

\section{Envelope curves}

Correlation analysis on the extensive database was performed by plotting data pairs for $\mathrm{N}$ concentration and grain yield in a coordinate system and envelope curves were drawn for each set of points (Izsáki, 2014; Helget, 2016; Izsáki, 2017). Values located 
along the envelope curve represent cases when factors influencing the yield have optimum values and the yield is only influenced by the $\mathrm{N}$ concentration. Those located below the envelope curve indicate that one or more yield-influencing factors are not optimum, so the yield level does not depend only on the $\mathrm{N}$ nutritional status. The higher the yield level for which the optimum nutrient supply level is determined, the narrower the optimum range, while the range is wider for lower yield levels.

\section{Results}

\section{Effect of $N$ supply levels on the macroelement content of winter barley}

The effect of $\mathrm{N}$ basic fertiliser $\left(\mathrm{N}_{0}=0, \mathrm{~N}_{1 \mathrm{~B}}=40, \mathrm{~N}_{2 \mathrm{~B}}=80, \mathrm{~N}_{3 \mathrm{~B}}=120 \mathrm{~kg} \mathrm{ha}^{-1}\right)$ on the $\mathrm{N}, \mathrm{P}$ and $\mathrm{K}$ contents of winter barley in the tillering phase, averaged over the $\mathrm{P}$ and $\mathrm{K}$ treatments, can be evaluated from the data presented in Table 3.

Table 3. Effect of $N$ supplies on the $N$-, $P$ - and $K$-concentrations of winter barley at the tillering, (Szarvas, 2006-2008, 2011-2012)

\begin{tabular}{|c|c|c|c|c|c|c|}
\hline \multirow{2}{*}{ Year } & \multicolumn{4}{|c|}{ Nutrient concentration (\%) } & \multirow{2}{*}{$\mathbf{L S D}_{\mathbf{5} \%}$} & \multirow{2}{*}{ Average } \\
\hline & $\mathbf{N}_{\mathbf{0}}$ & $\mathbf{N}_{1 B}$ & $\mathbf{N}_{2 B}$ & $\mathbf{N}_{3 B}$ & & \\
\hline \multicolumn{7}{|c|}{$\mathrm{N} \%$} \\
\hline 2006 & $3.04^{\mathrm{d}}$ & $3.60^{\mathrm{c}}$ & $4.39^{b}$ & $4.89^{\mathrm{a}}$ & 0.20 & 3.98 \\
\hline 2007 & $3.42^{\mathrm{a}}$ & $3.68^{\mathrm{a}}$ & $4.09^{\mathrm{a}}$ & $4.55^{\mathrm{a}}$ & 0.58 & 3.94 \\
\hline 2008 & $4.07^{\mathrm{d}}$ & $4.70^{\mathrm{c}}$ & $5.28^{b}$ & $5.61^{\mathrm{a}}$ & 0.26 & 4.91 \\
\hline 2011 & $3.00^{b}$ & $3.27^{\mathrm{a}}$ & $3.47^{\mathrm{a}}$ & $3.66^{\mathrm{a}}$ & 0.29 & 3.35 \\
\hline 2012 & $2.94^{\mathrm{c}}$ & $3.67 \mathrm{c}$ & $3.85^{\mathrm{b}}$ & $4.11^{\mathrm{a}}$ & 0.32 & 3.64 \\
\hline \multicolumn{7}{|c|}{$\mathrm{P} \%$} \\
\hline 2006 & $0.57^{c}$ & $0.60^{\mathrm{b}}$ & $0.63^{\mathrm{a}}$ & $0.63^{\mathrm{a}}$ & 0.02 & 0.61 \\
\hline 2007 & $0.44^{\mathrm{b}}$ & $0.48^{b}$ & $0.58^{\mathrm{a}}$ & $0.57^{\mathrm{a}}$ & 0.05 & 0.52 \\
\hline 2008 & 0.63 & 0.67 & 0.65 & 0.65 & NS & 0.65 \\
\hline 2011 & 0.38 & 0.40 & 0.41 & 0.41 & $\mathrm{NS}$ & 0.40 \\
\hline 2012 & 0.33 & 0.30 & 0.29 & 0.32 & NS & 0.31 \\
\hline \multicolumn{7}{|c|}{$\mathrm{K} \%$} \\
\hline 2006 & 3.93 & 4.02 & 4.02 & 4.03 & NS & 4.00 \\
\hline 2007 & $3.53^{c}$ & $4.00^{b}$ & $4.49^{\mathrm{a}}$ & $4.69^{a}$ & 0.38 & 4.18 \\
\hline 2008 & $3.91^{\mathrm{a}}$ & $4.13^{\mathrm{a}}$ & $4.14^{\mathrm{a}}$ & $4.21^{\mathrm{a}}$ & 0.23 & 4.10 \\
\hline 2011 & $2.81^{\mathrm{a}}$ & $3.00^{\mathrm{a}}$ & $3.07^{\mathrm{a}}$ & $3.07^{\mathrm{a}}$ & 0.25 & 2.99 \\
\hline 2012 & 3.89 & 4.11 & 4.16 & 4.12 & $\mathrm{NS}$ & 4.07 \\
\hline
\end{tabular}

NS: non-significant. Values in each row followed by the same letters are not significantly different at $\mathrm{p}<0.05$ according to Student's t-test

Without $\mathrm{N}$ fertilisation the $\mathrm{N}$ content of the total aboveground organs of barley ranged over a relatively narrow interval (2.94-3.42\%) in four of the five years. In the year that had average but favourably distributed rainfall supplies the $\mathrm{N}$ concentration reached a level of around $4 \%$. Regardless of the year, increasing rates of $\mathrm{N}$ fertiliser led to significant increases in the $\mathrm{N}$ concentration of barley compared with the control given no $\mathrm{N}$ fertiliser $\left(\mathrm{N}_{0}\right)$. The $\mathrm{N}$ content of the aboveground shoot reached a maximum concentration of $4.11-5.61 \%$ in the $\mathrm{N}_{3 \mathrm{~B}}$ treatment $\left(120 \mathrm{~kg} \mathrm{~N} \mathrm{ha}^{-1}\right.$ year $\left.^{-1}\right)$ except in 2011 . The winter half of the 2010/2011 growing season was extremely wet, and the $188 \mathrm{~mm}$ precipitation recorded in November and December leached a considerable quantity of $\mathrm{NO}_{3}-\mathrm{N}$ out of the soil of $\mathrm{N}$-fertilised treatments, with the result that the $\mathrm{N}$ concentration 
of barley was the lowest in this year. The $\mathrm{P}$ concentration of barley at tillering was greatly influenced by the year and ranged from $0.32-0.65 \%$ in the $\mathrm{N}_{3}$ treatment.

Even though the experiment was set up in 1989 the $\mathrm{AL}-\mathrm{K}_{2} \mathrm{O}$ content of the ploughed layer was $322 \mathrm{mg} \mathrm{kg}^{-1}$, which dropped to $199 \mathrm{mg} \mathrm{kg}^{-1}$ by autumn 2006 , in the $16^{\text {th }}$ year of the experiment, without $\mathrm{K}$ fertilisation. The soil was also well supplied with $\mathrm{K}$, and improvements in the $\mathrm{N}$ supply level increased the $\mathrm{K}$ content of barley at tillering in three of the five years. There was also a tendency for $\mathrm{N}$ fertilisation to increase the $\mathrm{K}$ concentration in the other two years. Except in the 2010/2011 growing season, the K concentrations exhibited little difference within each $\mathrm{N}$ supply level, with a value of $4.03-4.69 \%$ in the $\mathrm{N}_{3}$ treatment.

The effect of basic $\mathrm{N}$ fertilisation on the $\mathrm{Na}, \mathrm{Ca}$ and $\mathrm{Mg}$ contents of winter barley in the tillering phase, averaged over the $\mathrm{P}$ and $\mathrm{K}$ treatments, can be seen from the data in Table 4.

Table 4. Effect of $\mathrm{N}$ supplies on the $\mathrm{Na}, \mathrm{Ca}$ and $\mathrm{Mg}$ content of winter barley at the tillering, (Szarvas, 2006-2008, 2011-2012)

\begin{tabular}{|c|c|c|c|c|c|c|}
\hline \multirow{2}{*}{ Year } & \multicolumn{4}{|c|}{ Nutrient concentration $(\%)$} & \multirow{2}{*}{$\mathbf{L S D}_{5 \%}$} & \multirow{2}{*}{ Average } \\
\hline & $\mathbf{N}_{\mathbf{0}}$ & $\mathbf{N}_{1 B}$ & $\mathbf{N}_{2 B}$ & $\mathbf{N}_{3 B}$ & & \\
\hline \multicolumn{7}{|c|}{$\mathrm{Na} \%$} \\
\hline 2006 & $0.23^{b}$ & $0.27^{\mathrm{b}}$ & $0.35^{\mathrm{a}}$ & $0.39^{\mathrm{a}}$ & 0.06 & 0.31 \\
\hline 2007 & 0.36 & 0.27 & 0.25 & 0.28 & NS & 0.29 \\
\hline 2008 & $0.31^{\mathrm{a}}$ & $0.36^{\mathrm{a}}$ & $0.40^{\mathrm{a}}$ & $0.41^{\mathrm{a}}$ & 0.05 & 0.37 \\
\hline 2011 & 0.16 & 0.15 & 0.18 & 0.19 & NS & 0.17 \\
\hline 2012 & 0.21 & 0.19 & 0.23 & 0.22 & NS & 0.21 \\
\hline \multicolumn{7}{|c|}{$\mathrm{Ca} \%$} \\
\hline 2006 & $0.41^{\mathrm{b}}$ & $0.46^{\mathrm{a}}$ & $0.48^{\mathrm{a}}$ & $0.51^{\mathrm{a}}$ & 0.03 & 0.46 \\
\hline 2007 & $0.43^{b}$ & $0.48^{\mathrm{a}}$ & $0.50^{\mathrm{a}}$ & $0.52^{\mathrm{a}}$ & 0.04 & 0.48 \\
\hline 2008 & 0.55 & 0.51 & 0.51 & 0.53 & NS & 0.52 \\
\hline 2011 & $0.41^{\mathrm{a}}$ & $0.44^{\mathrm{a}}$ & $0.46^{\mathrm{a}}$ & $0.51^{\mathrm{a}}$ & 0.06 & 0.46 \\
\hline 2012 & 0.54 & 0.57 & 0.57 & 0.50 & NS & 0.55 \\
\hline \multicolumn{7}{|c|}{$\mathrm{Mg} \%$} \\
\hline 2006 & $0.18^{\mathrm{a}}$ & $0.20^{\mathrm{a}}$ & $0.22^{\mathrm{a}}$ & $0.23^{\mathrm{a}}$ & 0.02 & 0.21 \\
\hline 2007 & 0.21 & 0.21 & 0.22 & 0.23 & NS & 0.22 \\
\hline 2008 & 0.23 & 0.24 & 0.25 & 0.26 & NS & 0.24 \\
\hline 2011 & 0.17 & 0.17 & 0.18 & 0.19 & NS & 0.18 \\
\hline 2012 & 0.22 & 0.20 & 0.22 & 0.23 & NS & 0.22 \\
\hline
\end{tabular}

NS: non-significant. Values in each row followed by the same letters are not significantly different at $\mathrm{p}<0.05$ according to Student's t-test

For most field crops, $\mathrm{Na}$ is not one of the essential macroelements, but winter barley takes up almost as much $\mathrm{Na}$ as $\mathrm{Mg}$, especially on solonetz soils well supplied with $\mathrm{Na}$. In two of the five years $\mathrm{N}$ fertilisation was found to induce a significantly greater rate of $\mathrm{Na}$ incorporation compared with the $\mathrm{N}_{0}$ treatment. The $\mathrm{Na}$ concentration in the tillering phase differed considerably in the different years, with values ranging from $0.19-0.41 \%$ in the $\mathrm{N}_{3 \mathrm{~B}}\left(120 \mathrm{~kg} \mathrm{ha}^{-1} \mathrm{~N}\right)$ treatment. The Ca content of barley exhibited a significant increase with better $\mathrm{N}$ supplies in three of the years. The Ca content was not greatly influenced by the year. On this soil, which is extremely well supplied with $\mathrm{Mg}$, a slight but significant increase in $\mathrm{Mg}$ concentration as the result of $\mathrm{N}$ fertilisation could only be detected in one year. Depending on the year and the $\mathrm{N}$ supply level, the $\mathrm{Mg}$ content of barley at tillering ranged from $0.17-0.26 \%$. 


\section{Correlations between nutrient concentrations and the yield}

The experimental data revealed clear differences in the $\mathrm{N}$ concentration of barley leaves at tillering in the various $\mathrm{N}$ treatments. Diagnostic plant analysis is only of practical interest if a correlation exists between the leaf $\mathrm{N}$ concentration and the yield, allowing limiting values to be determined for the $\mathrm{N}$ nutritional status of winter barley. Based on the correlation between the leaf $\mathrm{N}$ concentration of winter barley in the tillering phase and the grain yield (Fig. 2), the limiting value of satisfactory $\mathrm{N}$ supplies at a yield level of over $5.5 \mathrm{tha}^{-1}$ is $3.70-5.80 \mathrm{~N} \%$.

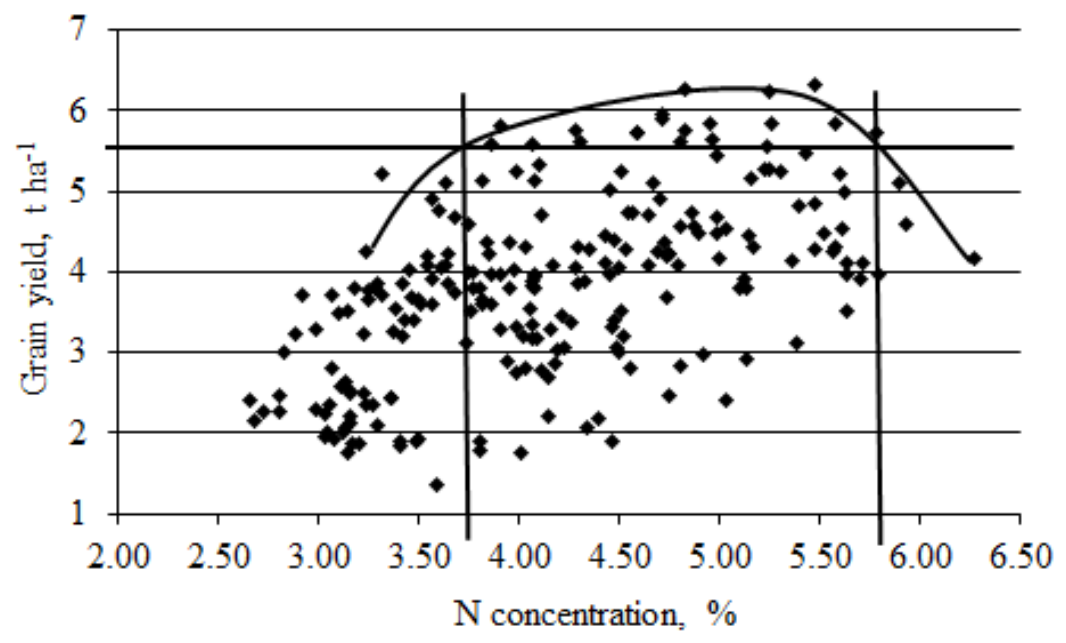

Figure 2. Relationship between the $N$-concentration of leaf at the tillering and the grain yield (Szarvas, 2006-2008, 2011-2012)

The limiting values for satisfactory supplies of the other macroelements were determined by plotting the $\mathrm{P}, \mathrm{K}, \mathrm{Na}, \mathrm{Ca}$ and $\mathrm{Mg}$ concentrations associated with grain yield in a coordinate system and then reading off the macroelement concentrations corresponded to a yield level that was at least $90 \%$ of the maximum value (Figs. 3-7).

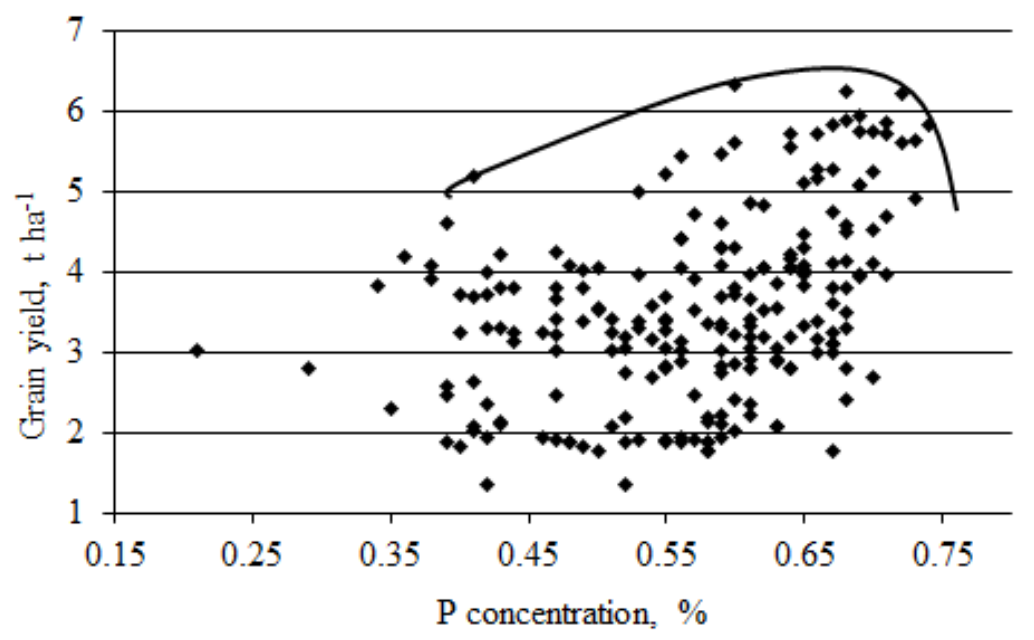

Figure 3. The limiting values for satisfactory P supply (Szarvas, 2006-2008, 2011-2012) 


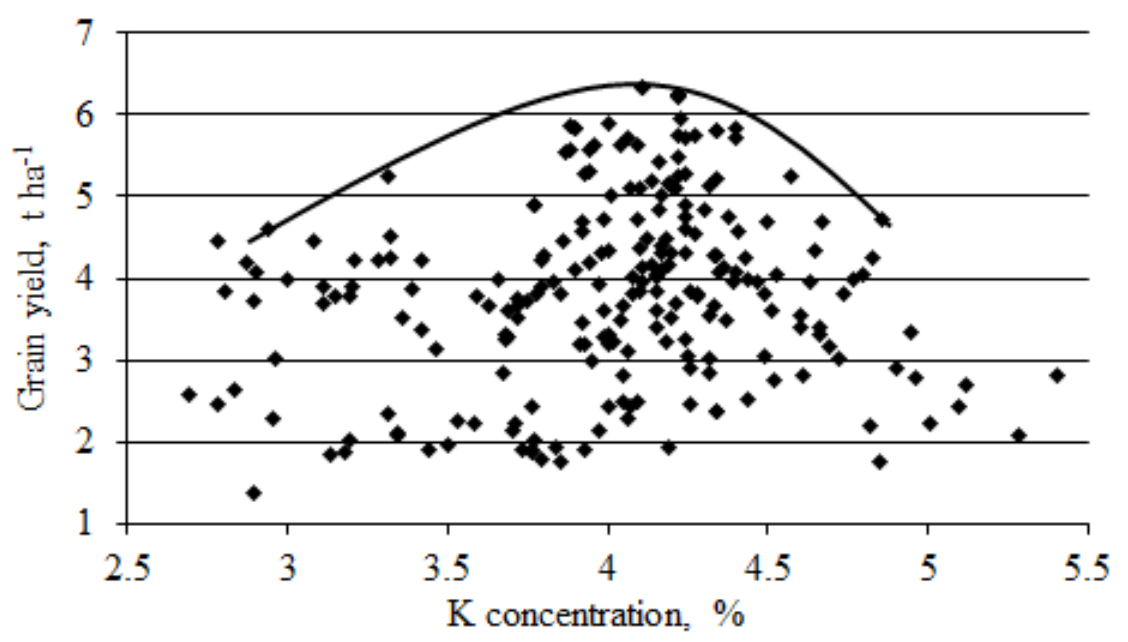

Figure 4. The limiting values for satisfactory K supply (Szarvas, 2006-2008, 2011-2012)

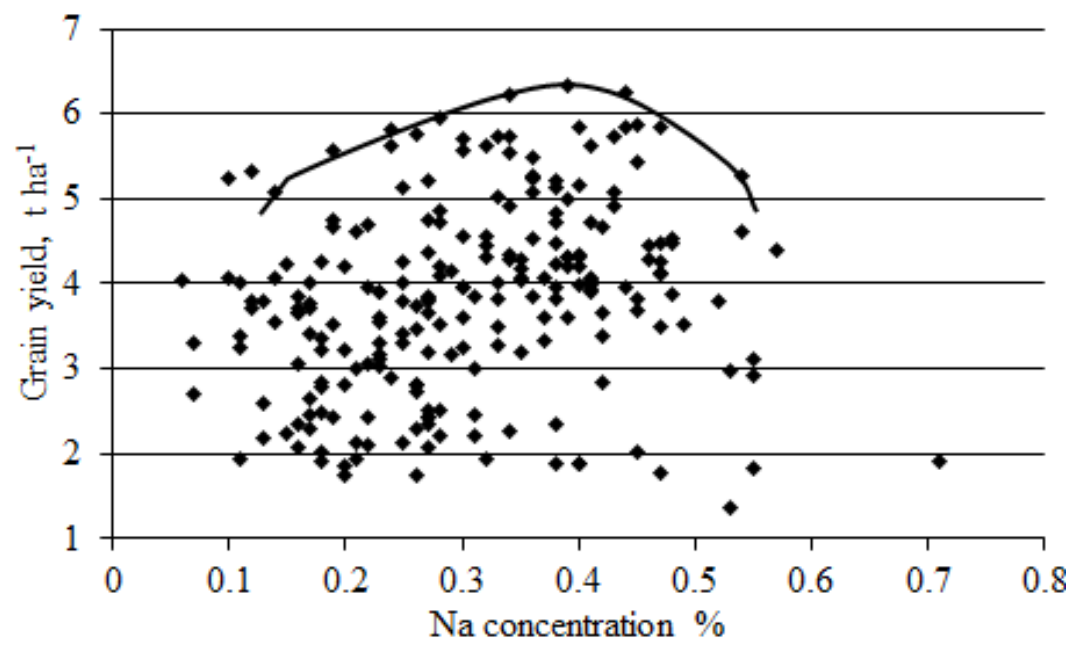

Figure 5. The limiting values for satisfactory Na supply (Szarvas, 2006-2008, 2011-2012)

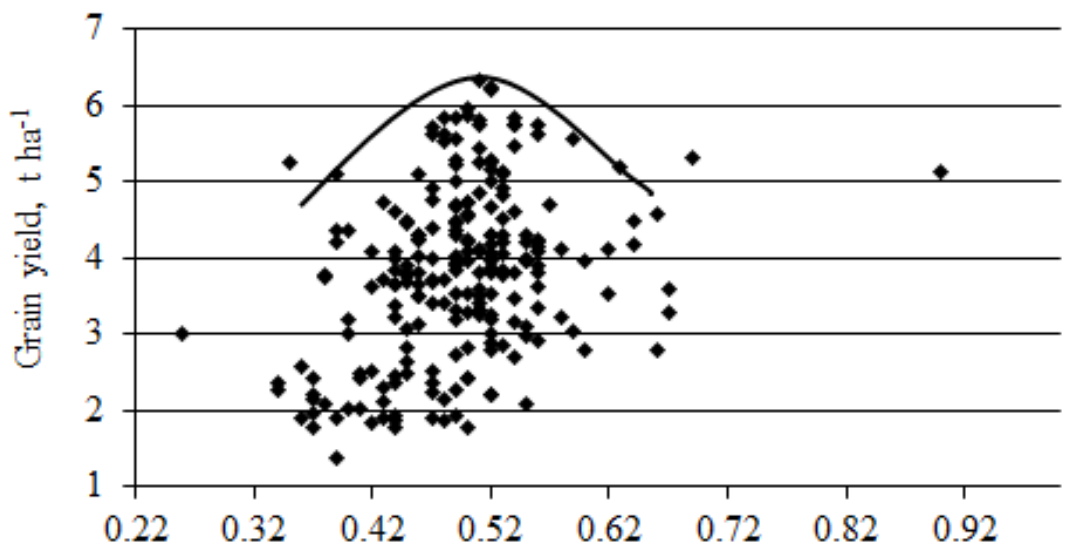

Ca concentration, \%

Figure 6. The limiting values for satisfactory Ca supply (Szarvas, 2006-2008, 2011-2012) 


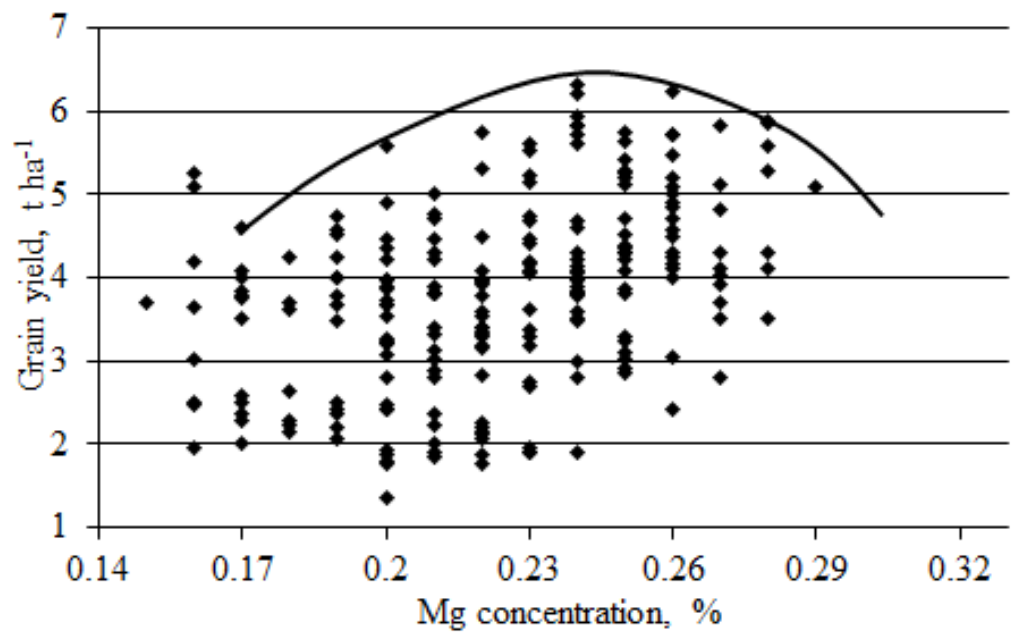

Figure 7. The limiting values for satisfactory Mg supply (Szarvas, 2006-2008, 2011-2012)

\section{Discussion}

In a pot experiment on winter barley in the tillering phenophase, Kostadinova (2014) found that the application of mineral fertiliser at rates of $200 \mathrm{mg} \mathrm{kg}^{-1} \mathrm{P}_{2} \mathrm{O}_{5}$ and $200 \mathrm{mg}$ $\mathrm{kg}^{-1} \mathrm{~K}_{2} \mathrm{O}$ without $\mathrm{N}$ fertiliser resulted in leaf $\mathrm{N}$ concentrations of $2.15 \%$, which rose by more than $50 \%$ as the $\mathrm{N}$ supplies increased. Kádár and Csathó (2015) examined the effect of $\mathrm{N}$ fertilisation on the nutrient content of winter barley at tillering in a soil containing $128 \mathrm{mg} \mathrm{kg}^{-1} \mathrm{AL}-\mathrm{P}_{2} \mathrm{O}_{5}$ and $243 \mathrm{mg} \mathrm{kg}^{-1} \mathrm{AL}-\mathrm{K}_{2} \mathrm{O}$ and reported that without $\mathrm{N}$ fertilisation the leaf $\mathrm{N}$ content was $1.86 \%$, which rose significantly to $3.03 \%$ at a dose of $200 \mathrm{~kg} \mathrm{ha}^{-1} \mathrm{~N}$, tending to decline again at the maximum dose of $300 \mathrm{~kg} \mathrm{ha}^{-1} \mathrm{~N}$. In the opinion of Mills and Jones (1996) ranges of sufficiency are most commonly used in assessment of plant nutrition. In the present work the satisfactory $\mathrm{N}$ concentration for winter barley at tillering was found to be $3.70-5.80 \%$, which deviated somewhat from the optimum $\mathrm{N}$ concentrations given by other authors. Fageria (2014) determined a very narrow range of satisfactory $\mathrm{N}$ concentrations (4.7-5.1\%), while Reuter and Robinson (1997) reported a fairly wide range $(2.5-5.0 \%)$. Under Hungarian conditions Elek and Kádár (1980) established a value of 4.70-5.25 N\%. On this soil, which is well supplied with $\mathrm{P}$, rising $\mathrm{N}$ supplies only led to a significant increase in the $\mathrm{P}$ content of barley in two years. According to Kádár and Csathó (2015) better N supplies reduced the P concentration of winter barley in the tillering phase, while in the present work the maximum P concentration was recorded in the $\mathrm{N}_{2}$ treatment. Sanchez (2007) considers the value above $0.4 \mathrm{P}$ concentration satisfactory. Both Elek and Kádár (1980) and Kádár (2012) stated that a $\mathrm{P}$ concentration of $0.4-0.5 \%$ represented satisfactory $\mathrm{P}$ supplies in winter barley, while a value of $0.45-0.75 \%$ was found in the present work and Reuter and Robinson (1997) reported an optimum range of 0.3-0.6\%. In agreement with the present results, Kádár (2012) and Kádár and Csathó (2015) reported that better $\mathrm{N}$ supplies stimulated the cation uptake of winter barley. A K concentration of 4.2-5.0\% was found by Elek and Kádár (1980) to represent satisfactory K nutritional status in winter barley at tillering, while this was later modified by Kádár (2012) to 3-4\%. Reuter and Robinson (1997) considered a wider range of values to be acceptable (3.5$5.0 \mathrm{~K} \%$ ), the same range as found in the present work. If the Na concentration of barley in the tillering phenophase was higher than $0.8 \%$, this was judged by Reuter and Robinson (1997) to be toxic, while values below $0.50 \%$ were found to be satisfactory. 
The present results showed that the satisfactory $\mathrm{Na}$ content for winter barley at tillering was $0.20-0.60 \%$. In the case of $\mathrm{Ca}$ and $\mathrm{Mg}$ the present results were in good agreement with the limiting values given in the literature. Barczak (2008) has demonstrated that higher $\mathrm{N}$ supplies generally increased the content of macroelements in winter barley biomass in all the plant growth stages assayed. Kádár and Lásztity (1981) emphasised that nutrient ratios only provide information on the relative quantities of two nutrients, not on the actual quantity of the individual nutrients, so the knowledge of ratios alone is insufficient to determine whether the nutrients are present in optimum, excessive or deficient quantities. The quantity of a given nutrient in the plant depends on the available supplies of other nutrients and on the interactions between them (Füleky et al., 1999). Elek and Kádár (1980) pointed out that nutrient ratios are more constant and less dependent on plant age than the concentrations. Between $\mathrm{N}$ and $\mathrm{P}$ nutrients are positive interaction, but their physiological effects are antagonists of each other. The present results suggest that a satisfactory N/P ratio is in the range of 7.7-8.2, which is similar to the value of 8.3 recommended by Reuter and Robinson (1997), but lower than the 11.912.0 reported by Elek and Kádár (1980). In the case of the N/K ratio, which is negative interaction, similar values were determined in the present work $(1.1-1.2)$ to those given in the literature. According to Brar et al. (2011) the N/K interaction is dependent on the form of $\mathrm{N}$ supplied. The satisfactory $\mathrm{N} / \mathrm{Na}$ ratio calculated from the present data (9.618.5) was higher than the 5-10 optimum reported by Reuter and Robinson (1997). Higher ratios were also found for the $\mathrm{N} / \mathrm{Ca}$ and $\mathrm{N} / \mathrm{Mg}$ ratios $(9.2-9.6$ and 19.3-20.5, respectively) than those given by the same authors (5.0-8.3 and 16.6-17.5, respectively), while the $\mathrm{K} / \mathrm{Mg}$ and $\mathrm{Ca} / \mathrm{Mg}$ ratios found in the present work were similar to those given by Reuter and Robinson (1997).

The limiting values for satisfactory macroelement concentrations and the associated nutrient ratios are presented for winter barley in the tillering phenophase in Table 5.

Table 5. The limiting values for satisfactory nutrient supplies of winter barley at tillering (Feekes 4-5)

\begin{tabular}{c|c|c}
\hline \multirow{2}{*}{ Nutrient } & \multicolumn{2}{|c}{ Nutrient concentrations and ratios } \\
\cline { 2 - 3 } & Own investigation & * Based on the literature data \\
\hline $\mathrm{N} \%$ & $3.70-5.80$ & $2.5-5.25$ \\
\hline $\mathrm{P} \%$ & $0.45-0.75$ & $0.20-0.60$ \\
\hline $\mathrm{K} \%$ & $3.50-5.02$ & $2.50-5.00$ \\
\hline $\mathrm{Na} \%$ & $0.20-0.60$ & $<0.50$ \\
\hline $\mathrm{Ca} \%$ & $0.40-0.60$ & $0.20-1.00$ \\
\hline $\mathrm{Mg} \%$ & $0.18-0.30$ & $0.14-0.30$ \\
\hline $\mathrm{N} / \mathrm{P}$ & $7.7-8.2$ & $6.4-8.8$ \\
\hline $\mathrm{N} / \mathrm{K}$ & $1.1-1.2$ & $0.7-1.1$ \\
\hline $\mathrm{N} / \mathrm{Na}$ & $9.7-18.5$ & $5.0-10.5$ \\
\hline $\mathrm{N} / \mathrm{Ca}$ & $9.3-9.7$ & $5.3-8.3$ \\
\hline $\mathrm{N} / \mathrm{Mg}$ & $19.3-20.6$ & $16.7-17.5$ \\
\hline $\mathrm{K} / \mathrm{Na}$ & $8.3-17.5$ & $7.0-10.0$ \\
\hline $\mathrm{K} / \mathrm{Mg}$ & $16.7-19.4$ & $16.7-23.3$ \\
\hline $\mathrm{Ca} / \mathrm{Mg}$ & $2.0-2.2$ & $2.0-3.3$ \\
\hline
\end{tabular}

* Reuter and Robinson, 1997; Elek and Kádár, 1980; Sanchez, 2007; Plank and Donohue, 2000 


\section{Conclusions}

1. Rising $\mathrm{N}$ supply levels gradually increased the $\mathrm{N}$ content of winter barley at the tillering phenophase, reaching a maximum (4.11-5.61 N\%) at the $120 \mathrm{~kg} \mathrm{~N}$ ha ${ }^{1}$ year $^{-1}$ dose.

2. The soil of the long-term fertilisation experiment is well supplied with phosphorus, the $\mathrm{P}$ concentration of barley at tillering was greatly influenced by the year, than $\mathrm{N}$ supply and ranged from $0.32-0.65 \%$ in the $\mathrm{N}_{3 \mathrm{~B}}$ treatment.

3. On this soil, which was also well supplied with $\mathrm{K}, \mathrm{N}$ fertilisation enhanced the $\mathrm{K}$ concentration of winter barley in most years.

4. $\mathrm{N}$ fertilisation generally had no influence on the $\mathrm{Na}, \mathrm{Ca}$ and $\mathrm{Mg}$ concentrations of barley.

5. In the tillering phenophase the nutritional status of winter barley was satisfactory at the following concentrations: $3.70-5.80 \mathrm{~N} \%, 0.45-0.75 \mathrm{P} \%$, $3.50-5.02 \mathrm{~K} \%, 0.20-0.60 \mathrm{Na} \%, 0.40-0.60 \mathrm{Ca} \%$ and $0.18-0.30 \mathrm{Mg} \%$.

6. The aim of experimental work was to develop fertilization consultancy with plant analysis, practical guidance for leaf fertilization.

\section{REFERENCES}

[1] Armstrong, D. L. (1998): Potassium. Better Crops with Plant Food. - A Publication of the International Plant Nutrition Institute, Peachtree Corners, Georgia.

[2] Barczak, B. (2008): Contents and rations of mineral components in winter barley biomass cultivated under conditions of different nitrogen fertilisation. - Journal of Elementology 13: 291-300.

[3] Brar, M. S., Bijay-Singh, S. K., Srinivasarao, CH. (2011): Role of Potassium Nutrition in Nitrogen Use Efficiency in Cereals. Optimizing Crop Nutrition. - International Potash Institute, Switzerland.

[4] Buzás, I., Fekete, A., Buzás, I.-né, Csengei, P.-né, Kovács, A.-né. (1979): Principles of Fertilization and Estimation of Doses to be Applied on the Farms I-II. Part. - MÉM NAK, Budapest [in Hungarian].

[5] Debreczeni, B.-né, Sárdi, K. (1999): The Role of Nutrients and Water in Plant Life. - In: Füleky, G. (ed.) Nutrition Management. Mezőgazda Kiadó, Budapest [in Hungarian].

[6] Dobermann, A. R. (2005): Nitrogen Use Efficiency - State of the Art. - Faculty Publication, Agronomy and Horticulture Department, University of Nebraska, Lincoln.

[7] Elek, É., Kádár, I. (1980): Sampling Methods of Permanent Plants and Field Crops. MÉM NAK, Budapest [in Hungarian].

[8] Fageria, N. K. (2014): Nitrogen Management in Crop Production. - CRC Press, Boca Raton.

[9] Füleky, Gy., Rajkainé Végh, K., Tolner, L. (1999): Nutrition Principles and Methods. In: Füleky, G. (ed.) Nutrition Management. Mezőgazda Kiadó, Budapest [in Hungarian].

[10] Helget, R. L. (2016): Soybean yield and plant response to phosphorus fertilization. Theses and Dissertations, Paper 1075.

[11] Izsáki, Z. (2014): Effect of phosphorus supplies on the nutritional status of maize (Zea mays L.). - Communications is Soil Science and Plant Analysis 45: 516-529.

[12] Izsáki, Z. (2015): Results of the long-term fertilisation field trials at Szarvas I. 19902010. Maize, sugar beet, oat, linseed and silage corn. - Agroinform Kiadó és Nyomda Kft., Budapest [in Hungarian].

[13] Izsáki, Z. (2017): Effect of potassium supplies on the nutritional status of maize (Zea mays L.). - Communications is Soil Science and Plant Analysis 48: 2347-2358. 
[14] Jones, J. J. Jr. (1998): Field Sampling Procedures for Conducting a Plant Analysis. - In: Kalra, Y. P. (ed.) Handbook of Reference Methods for Plant Analysis, CRC Press, Boca Raton.

[15] Kádár, I. (1992): Principles and Methods in Plant Nutrition. - Magyar Tudományos Akadémia Talajtani és Agrokémiai Kutató Intézete, Budapest [in Hungarian].

[16] Kádár, I. (2012): Results of the Long-Term Fertilisation Field Trials at Nagyhörcsök 1973-1983. - Magyar Tudományos Akadémia ATK Talajtani és Agrokémiai Intézet, Budapest [in Hungarian].

[17] Kádár, I., Csathó, P. (2015): Interactions between nitrogen and copper in a long-term field experiment in winter barley. - Növénytermelés 64: 45-58.

[18] Kádár, I., Lásztity, B. (1981): Change in the nutrient ratios of winter wheat during a vegetation period. - Agrokémia és Talajtan 30: 291-303.

[19] Kostadinova, S. (2014): Grain yield and protein of barley in dependence of phosphorus and potassium nutrition. - Scientific Papers. Series A. Agronomy 57: 232-235.

[20] Mazur, Z., Mazur, T. (2015): Effects of Long-term organic and mineral fertilizer applications on soil nitrogen content. - Polish Journal of Environmental Studies 24: 2073-2078.

[21] Mengel, K. (1972): Ernährung und Stoffwechsel der Pflanze. 4th ed. - Gustav Fisher Verlag, Jena [in German].

[22] Mills, H., Jones, J. B. Jr. (1996): Plant Analysis Handbook II: A Practical Sampling, Preparation, Analysis, and Interpretation Guide. - Micro-Macro Publishing, Athens (GA).

[23] Munson, R. D. (1998): Principles of Plant Analysis. - In: Kalra, Y. P. (ed.) Handbook of Reference Methods for Plant Analysis, CRC Press, Boca Raton.

[24] Németh, T., Horváth, J., Pálmai, O. (2010): Nutrition Management. - In: Radics, L. (ed.) Sustainable Approach to Field Crops. Agroinform Kiadó, Budapest [in Hungarian].

[25] Plank, C. O., Donohue, S. J. (2000): Small Grain (Barley, Oats, Rye, Wheat). - In: Campbell, C. R. (ed.) Reference Sufficiency Ranges for Plant Analysis in the Southern Region of the United States. North Carolina of Agriculture and Consumer Services Agronomic Division, Raleigh.

[26] Reuter, D. J., Robinson, J. B. (1997): Plant Analysis: An Interpretation Manual. 2nd ed. CSIRO Publishing; Collingwood.

[27] Roberts, T. L. (2008): Improving nutrient use efficiency. - Turkish Journal of Agriculture and Forestry 32: 177-182.

[28] Roy, R. N., Finck, A., Blair, G. J., Tandon, H. L. S. (2006): Plant nutrition for food security: A guide for integrated nutrient management. - Food and Agriculture Organization of the United Nations, Rome.

[29] Sanchez, C. H. A. (2007): Phosphorus. - In: Barker, A. V., Pilbean, D. J. (ed.) Handbook of Plant Nutrition. Essential Elements-Macronutrients. CRC Press, Boca Raton.

[30] Sebilo, M., Mayer, B., Nicolardot, B., Pinay, G., Mariotti, A. (2013): Long-term fate of nitrate fertilizer in agricultural soils. - Proceedings of the National Academy of Sciences of the United States of America 110: 18185-18189.

[31] Shafi, M., Bakht, J., Jalal, F., Khan, M. A., Khattak, S. G. (2011): Effect of nitrogen application on yield and yield components of barley (Hordeum vulgare L.). - Pakistan Journal of Botany 43: 1471-1475.

[32] Shah, J. M., Bukhari, S. A. H., Zeng, J., Quan, X., Essa, A., Noor, M., Zhang. G. (2017): Nitrogen $(\mathrm{N})$ metabolism related enzyme activities, cell ultrastructure and nutrient contents as affected by $\mathrm{N}$ level and barley genotype. - Journal of Integrative Agriculture 16: 190-198.

[33] Tarnawa, Á., Czerődiné Kempf, L., NyáraI-Horváth, F., Máté, A., Szentpétery ZS. (2017): The comparison of spring to early summer SPAD values of various winter cereals. - Columella 4: 73-77. 
[34] Usherwood, N. R., Segars, W. I. (2001): Nitrogen interactions with phosphorus and potassium for optimum crop yield, nitrogen use effictiveness and environmental stewardship. - The Scientific World Journal. 1: 57-60.

[35] Wang, C. Y., Xiao, H. G., Liu, J., Zhou, J. W., Du, D. L. (2016): Insights into the effects of simulated nitrogen deposition on leaf functional traits of Rhus typhina. - Polish Journal of Environment Studies 25: 1279-1284.

[36] West, J. R., Ruark, M. D., Bussan, A. J., Colquhoun, J. B., Silva, E. M. (2016): Nitrogen and weed management for organic sweet corn production on loamy sand. - Agronomy Journal 108: 758-769. 